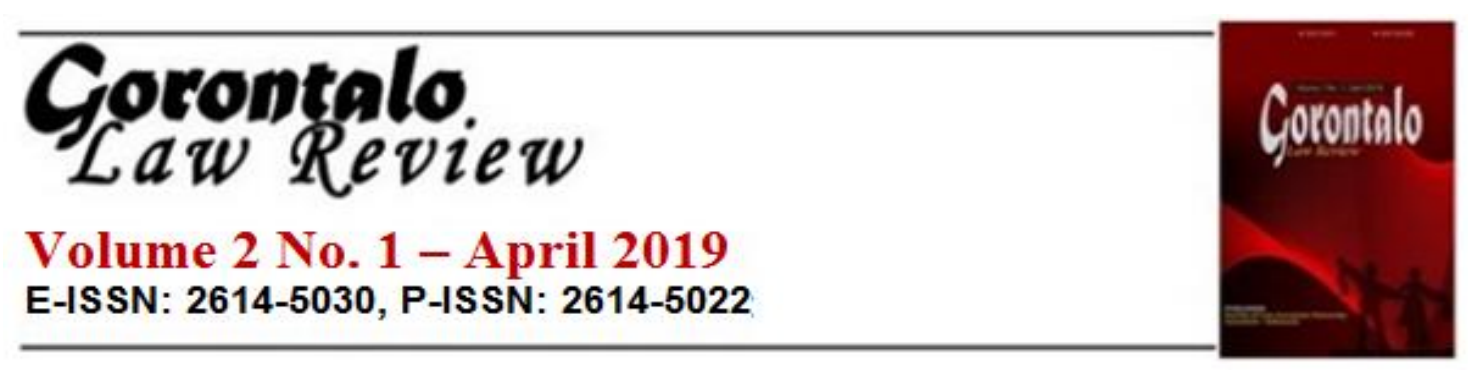

\title{
EKSISTENSI PENGADILAN HAK ASASI MANUSIA TERHADAP PENEGAKAN HAK ASASI MANUSIA DALAM SISTEM PERADILAN
}

\author{
Fatma Faisal \\ Fakultas Hukum Universitas Ichsan Gorontalo \\ fatmaf441@gmail.com
}

\begin{abstract}
Abstrak
Pengadilan Hak Asasi Manusia merupakan jenis pengadilan yang khusus untuk mengadili kejahatan genosida dan kejahatan terhadap kemanusiaan.Pengadilan ini dikatakan khusus karena dari segi penamaan bentuk pengadilannya sudah secara spesifik menggunakan istilah pengadilan HAM dan kewenangan pengadilan ini juga mengadili perkara-perkara tertentu. Penelitian ini dilakukan dengan bertujuan untuk: (1)Menganalisis dan Menjelaskan eksistensi pengadilan Hak Asasi Manusia terhadap suatu perkara; (2) Menganalisis dan Menjelaskan peran pengadilan Hak Asasi Manusia dalam mewujudkan kepastian hukum pada sistem peradilan pidana. Metode yang digunakan dalam penelitian ini adalah metode penelitian hukum normatif atau doctrinal, yang melihat hukum sebagai sistim konseptual, sistim nilai dan sistim norma, sehingga bahan primer yang digunakan dalam penelitian ini adalah norma dasar yaitu Undang Undang Dasar Negara Republik Indonesia Tahun 1945, dan Peraturan perundangundangan serta Putusan-putusan Mahkamah Konstitusi yang berkaitan dengan penelitian ini. Analisis terhadap bahan-bahan hukum tersebut, dilakukan dengan menggunakan analisis isi (content analisys). Hasil penelitian ini menunjukkan bahwa: (1) Eksistensi pengadilan Hak Asasi Manusia terhadap suatu perkara masih banyak mengandung kelemahan yang mengakibatkan hambatan yuridis dalam penerapan Undang-Undang No. 26 Tahun 2000; (2) Pengadilan Hak Asasi Manusia dalam sistem peradilan pidana dapat mewujudkan kepastian hukum bahwa hukum acara yang digunakan dalam pengadilan Hak Asasi Manusia Ad Hoc sama yang digunakan dalam hukum acara pengadilan Hak Asasi Manusia yaitu menggunakan ketentuan dalam Undang-Undang No. 26 Tahun 2000.Agar penerapan Undang-Undang No. 26 Tahun 2000 berjalan dengan baik pemerintah perlu mengamandemen UndangUndang No. 26 Tahun 2000 agar secara lengkap menyesuaikan tindak pidana yang diatur yaitu kejahatan terhadap kemanusiaan dan kejahatan terhadap genosida yang seharusnya disertai dengan penjelasan mengenai unsur tindak pidananya.
\end{abstract}

Kata Kunci : Eksistensi; Pengadilan; Hak Asasi Manusia 


\begin{abstract}
Human Rights Court is a kind of law court particularly judging both the crimes against genocide and the crimes against humanity. Human rights court is said as particular law court because its naming form has been specifically using a term of human rights court and its authority has been judging certain cases. The aim of the study is: (1) to analyze and explain the existence of the human rights court against issues: (2) to analyze and explain the role of the court human rights in achieving legal certainty in the criminal judicial system. The method used in the study is a normative legal research methods related to doctrinal approach which review the law as a conceptual system, system of values and system of norms. Therefore, the primary material used in this study is the fundamental norms of the Constitution of the Republic of Indonesia Year 1945, both regulations and decisions of the Constitutional Court. Analysis of the legal materials is conducted by using content analysis (content analysis). The results of the study find out that: (1) the existence of human rights court against a case still has a lot of flaws causing legal obstacles in the implementation of Law No. 26 of 2000; (2) the human rights court in the criminal judicial system is able to bring legal certainty that procedural law used in Ad Hoc human rights court is the same as that used in human rights courts applied with the provisions of Law No. 26 of 2000.In order that the implementation of the law no. 26 of 2000 works well, the government needs to amend the law No. 26 of 2000 and completely match for the regulated criminal act that the crimes against humanity and crimes against genocide must be accompanied by an explanation of their criminal act elements.
\end{abstract}

\title{
Keywords: Existence; Courts; Human Rights
}

\section{PENDAHULUAN}

Pembukaan Undang - Undang Dasar Negara Republik Indonesia Tahun 1945 alenia IV menyatakan bahwa,untuk membentuk suatu Pemerintah Negara Indonesia yang melindungi segenap bangsa Indonesia dan seluruh tumpah darah Indonesia dan untuk memajukan kesejahteraan umum, mencerdaskan kehidupan bangsa, dan ikut melaksanakan ketertiban dunia yang berdasarkan kemerdekaan, perdamaian abadi dan keadilan sosial. Citacita negara untuk mewujudkan kemerdekaan bagi masyarakatnya diimplentasikan kembali pada Pasal $28 \mathrm{~J}$ ayat (1) Undang-Undang Dasar Negara Republik Indonesia 1945 yang isinya adalah :

"Setiap orang wajib menghormati hak asasi manusia orang lain dalam tertib kehidupan bermasyarakat, berbangsa, dan bernegara".

Wacana mengenai Hak Asasi manusia (HAM) dan pelanggarannya telah menjadi wacana yang memasuki babak dari setengah abad. Bahkan hingga kini masih menjadi topik yang aktual sampai beberapa abad yang akan datang, terutama di negara yang berdasar atas hukum di Negara Republik Indonesia.

Pelanggaran HAM berat merupakan extraordinary crimes (kejahatan luar biasa) yang mempunyai perumusan dan sebab timbulnya kejahatan yang berbeda dengan kejahatan atau tindak pidana umum.Dengan perumusan yang 
berbeda ini tidak mungkin menyamakan perlakukan dalam menyelesaikan masalahnya, artinya KUHP tidak dapat untuk menjerat secara efektif para pelaku pelanggaran HAM yang berat. Disamping itu sesuai dengan prinsip International Criminal Court (Pengadilan kriminal Internasional), khususnya prinsip universal yang tidak mungkin memperlakukan pelanggaran HAM berat sebagai extraordinary crimes dan adanya kualifikasi universal tentang crimes against humanity (kejahatan terhadap kemanusiaan) masyarakat mengharuskan didaya gunakannya pengadilan HAM yang bersifat khusus, yang mengandung pula acara pidana yang bersifat khusus.

Pengertian tentang perlunya peradilan yang secara khusus dengan aturan yang bersifat khusus pula inilah yang menjadi landasan pemikiran untuk adanya pengadilan khusus yang dikenal dengan pengadilan HAM. Alasan yuridis lainnya yang bisa menjadi landasan berdirinya pengadilan HAM adalah bahwa pengadilan HAM merupakan "the primary forum" untuk mengadili para pelanggar HAM berat.

Berdasarkan kondisi tentang perlunya instrumen hukum untuk berdirinya sebuah pengadilan HAM secara cepat maka pemerintah menerbitkan Peraturan Pemerintah Penganti Undang-Undang Nomor 1 Tahun 1999 tentang Pengadilan HAM. Perpu ini telah menjadi landasan yuridis untuk adanya penyelidikan kasus pelanggaran HAM berat di Timor-timur oleh Komnas HAM.Karena berbagai alasan Perpu Nomor 1 Tahun 1999 ini yang kemudian ditolak oleh DPR untuk menjadi undang-undang.

Setelah adanya penolakan Perpu tersebut diatas oleh DPR maka pemerintah mengajukan rancangan Undang-Undang tentang Pengadilan HAM. Dalam penjelasannya, pengajuan Rancangan Undang-Undang (RUU) tentang Pengadilan HAM adalah : Pertama, merupakan perwujudan tanggung jawab bangsa Indonesia sebagai salah satu anggota PBB. Dengan demikian merupakan salah satu misi yang mengembangkan tanggung jawab moral dan hukum dalam menjunjung tinggi dan melaksanakan deklarasi HAM yang ditetapkan oleh Perserikatan Bangsa-Bangsa (PBB), serta yang terdapat dalam berbagai instrumen hukum lainnya yang mengatur mengenai HAM yang telah dan atas diterima oleh negara Indonesia. Kedua, dalam rangka melaksanakan Tap MPR No.XVII/MPR/ 1998 tentang HAM dan sebagai tindak lanjut dari Pasal 104 ayat 1 Undang-undang Nomor 39 Tahun 1999.Ketiga, untuk mengatasi keadaan yang tidak menentu di bidang keamanan dan ketertiban umum, termasuk perekonomian nasional.

Penegakan dan perlindungan terhadap Hak Asasi Manusia (HAM) di Indonesia mencapai kemajuan ketika pada tanggal 6 November 2000 disahkannya Undang-undang Nomor 26 Tahun 2000 tentang Pengadilan HAM oleh Dewan Perwakilan Rakyat Republik Indonesia dan kemudian diundangkan tanggal 23 November 2000. Undang-Undang ini merupakan Undang-Undang yang secara tegas menyatakan sebagai Undang-Undang yang mendasari adanya pengadilan HAM di Indonesia yang akan berwenang untuk mengadili para pelaku pelanggaran HAM berat. Undang-Undang ini juga mengatur tentang adanya pengadilan HAM Ad Hoc yang akan berwenang untuk mengadili pelanggaran HAM berat yang terjadi di masa lalu.

Pengadilan HAM ini merupakan jenis pengadilan yang khusus untuk mengadili kejahatan genosida dan kejahatan terhadap kemanusiaan.Pengadilan ini dikatakan khusus karena dari segi penamaan bentuk pengadilannya sudah secara spesifik menggunakan istilah pengadilan HAM dan kewenangan pengadilan ini juga mengadili perkara-perkara tertentu.Istilah pengadilan HAM sering dipertentangkan dengan istilah 
peradilan pidana karena memang pada hakekatnya kejahatan yang merupakan kewenangan pengadilan HAM juga merupakan perbuatan pidana.UndangUndang Nomor 26 Tahun 2000 yang menjadi landasan berdirinya pengadilan HAM ini mengatur tentang beberapa kekhususan atau pengaturan yang berbeda dengan pengaturan dalam hukum acara pidana.

Pengaturan yang berbeda atau khusus ini mulai sejak tahap penyelidikan dimana yang berwenang adalah Komnas HAM sampai pengaturan tentang majelis hakim dimana komposisinya berbeda dengan pengadilan pidana biasa. Dalam pengadilan HAM ini komposisi hakim adalah lima orang yang mewajibkan tiga orang diantaranya adalah hakim ad hoc. Harapan atas adanya pengaturan yang sifatnya khusus ini adalah dapat berjalannya proses peradilan terhadap kasus-kasus pelanggaran HAM yang berat secara kompeten dan fair. Efek yang lebih jauh adalah putusnya rantai impunity (pembebasan dari hukuman) atas pelaku pelanggaran HAM yang berat dan bagi korban, adanya pengadilan HAM akan mengupayakan adanya keadilan bagi mereka.

Pembentukan Pengadilan HAM Ad Hoc ini merupakan implementasi dari Undang-Undang Nomor 26 Tahun 2000 tentang Pengadilan Hak Asasi Manusia.Terbentuknya Pengadilan HAM di Indonesia ini mempunyai arti penting dalam pemajuan dan perlindungan hak asasi manusia di Indonesia. Pertama, dibentuknya Pengadilan HAM dan Pengadilan HAM Ad Hoc ini akan membuka peluang penyelesaian pelanggaran hak asasi manusia yang terjadi di masa lalu maupun yang terjadi setelah dikeluarkannya Undang-Undang Nomor 26 Tahun 2000. Kedua, terbentuknya Pengadilan HAM dan Pengadilan HAM Ad Hoc menjadi salah satu tonggak dalam reformasi hukum di Indonesia.

Dalam hal pelanggaran hak asasi manusia yang berat yang terjadi sebelum diundangkannya Undang-undang ini, diperiksa dan diputus oleh Pengadilan HAM ad hoc. Hal inilah yang membedakan dengan pengadilan HAM permanen yang dapat memutus dan mengadili perkara pelanggaran HAM yang berat yang terjadi setelah diundangkannya Undang-Undang Nomor 26 Tahun 2000.

Legitimasi atas adanya pengadilan HAM ad hoc didasarkan pada Pasal 43 Undang-Undang Nomor 26 Tahun 2000. Ayat (1) menyatakan bahwa pelanggaran HAM berat yang terjadi sebelum diundangkannya undang-undang ini, diperiksa dan diputus oleh pengadilan HAM ad hoc. Ayat (2) menyatakan bahwa pengadilan HAM ad hoc sebagaimana dimaksud dalam ayat 1 dibentuk atas usul Dewan Perwakilan Rakyat berdasarkan peristiwa tertentu dengan keputusan presiden. Ayat (3) menyatakan bahwa pengadilan sebagaimana dimaksud dalam ayat (1) berada dalam pengadilan umum. Dalam penjelasannya, Dewan Perwakilan Rakyat yang juga sebagai pihak yang mengusulkan dibentuknya pengadilan HAM ad hoc mendasarkan usulannya pada dugaan terjadinya pelanggaran HAM yang berat yang dibatasi pada locus delicti dan tempos delicti tertentu yang terjadi sebelum diundangkannya undang-undang ini.

Sejarah penting perjuangan HAM mengencang di fase Orde baru yang berkuasa selama 33 tahun (1965-1998). Beriring dengan massifnya pelanggaran-pelanggaran HAM.Orde baru yang memerintah secara otoriter selama lebih dari 30 tahun telah melakukan berbagai tindakan pelanggaran Hak Asasi manusia (HAM) karena perilaku negara dan aparatnya.

Berbagai pelanggaran HAM yang terjadi belum pernah terselesaikan secara tuntas sedangkan gejala pelanggaran kian bertambah. Penyelesaian kasus Tanjung Priok, DOM Aceh, Papua dan kasus pelanggaran HAM berat di Timor-timur selama pra dan pasca jajak pendapat belum ada yang 
terselesaikan. Atas kondisi ini sorotan dunia internasional terhadap Indonesia sehubungan dengan maraknya pelanggaran HAM yang terjadi kian menguat terlebih sorotan atas pertanggung jawaban pelanggaran.

Terhadap kasus penculikan dan penghilangan paksa di Indonesia, DPR ditahun 2009 merekomendasikan 4 (empat) item kepada pemerintah, sebagai upaya penyelesaian penculikan dan penghilangan paksa di Indonesia, diantaranya adalah membentuk pengadilan HAM ad hoc, melakukan pencarian terhadap 13 orang yang oleh Komnas HAM masih dinyatakan hilang, merehabilitasi dan memberikan kompensasi terhadap keluarga korban yang hilang, dan meratifikasi konvensi anti penghilangan paksa.

\section{PEMBAHASAN}

\section{a. Konsep Dasar Hak Asasi Manusia}

Membicarakan Hak Asasi Manusia (HAM) berarti membicarakan dimensi kehidupan manusia. HAM ada bukan karena diberikan oleh masyarakat dan kebaikan dari Negara, melainkan berdasar martabatnya sebagai manusia (Franz, 2001). Kini HAM diperbincangkan dengan intens seiring dengan intensitas kesadaran manusia atas hak yang dimilikinya. Ia menjadi actual karena sering dilecehkan dalam sejarah manusia sejak awal hingga kurun waktu kini (Abdul, 2002).

Menurut Todung Mulya Lubis (2002), kesadaran akan perlunya jaminan HAM yang lebih luas sesungguhnya sangat kuat. Dalam perjalanan sejarah negeri ini kita mencatat bahwa pernah ada konstitusi, yaitu Konstitusi RIS UUD 1949 dan Konstitusi Sementara UUDS 1950 yang memuat secara komprehensif jaminan HAM yang secara umum dapat ditafsirkan sebagai adopsi dari pasalpasal HAM yang tertuang dalam Universal Declaration of Human Rights (1948).

Bila dikaji secara etimologi, hak merupakan unsur normatif yang berfungsi sebagai pedoman perilaku, melindungi kebebasan, kekebalan serta menjamin adanya peluang bagi manusia dalam menjaga harkat dan martabatnya.Sedangkan yang dimaksud dengan asasi berarti yang bersifat paling mendasar atau fundamental. Dengan demikian maka hak asasi berarti hak yang paling mendasar yang dimiliki oleh manusia sebagai fitrah, sehingga tidak satu pun makhluk atau siapa pun dapat mengitervensinya apalagi mencabutnya. Misalnya hak hidup, yang mana tak satu pun manusia memiliki kewenangan untuk mencabut kehidupan manusia lain. Istilah hak asasi manusia sendiri berasal dari istilah 'droits 1'home' (Perancis), 'menselijke rechten'(Belanda), 'fitrah'(Arab), dan 'human right' (Inggris).Istilah 'human right' semula berasal dari 'right of human' yang menggantikan istilah 'natural right' yang selanjutnya menurut Eleanor Roosevelt diubah dengan dengan istilah 'human right' yang memiliki konotasi lebih netral dan universal.

Miriam Budiarjo (2000), menyatakan hak asasi manusia adalah hak yang dimiliki manusia yang telah diperoleh dan dibawahnya bersamaan dengan kelahirannya di dalam kehidupan masyarakat. Dianggap bahwa beberapa hak itu dimilikinya tanpa perbedaan atas dasar bangsa, ras, agama, kelamin dank arena itu bersifat universal.

Koentjoro Poerbapranoto (2000), menyatakan hak asasi manusia adalah hak-hak yang dimiliki manusia menurut kodratnya yang tidak dapat dipisahkan dari hakikatnya sehingga sifatnya suci.

Hak asasi manusia diartikan dengan hak-hak dasar yang dimiliki setiap manusia dan dibawa sejak lahir serta merupakan pemberian Tuhan Yang Maha Esa (Madernis, 2016).

Hak asasi manusia dalam Islam sebagaimana termaktup dalam Fiqih 
menurut Masdar F. Mas'udi (1997) memiliki lima prinsip utama yaitu Hak perlindungan terhadap jiwa (hak hidup), Hak perlindungan keyakinan, Hak perlindungan terhadap akal pikiran, Hak perlindungan terhadap hak milik, dan Hak berkeluarga atau hak memperoleh keturunan dan mempertahankan nama baik.

\section{b. Pembentukan Pengadilan Hak Asasi Manusia \\ 1. Sejarah Lahirnya Pengadilan Hak Asasi Manusia}

Orde baru yang berkuasa selama 33 tahun (1965-1998) telah banyak dicatat melakukan pelanggaran-pelanggaran HAM. Ordebaru yang memerintah secara otoriter selama lebih dari 30 tahun telah melakukan berbagai tindakan pelanggaran HAM karena perilaku negara dan aparatnya Haryanto (1999).

Berbagai pelanggaran HAM yang terjadi belum pernah terselesaikan secara tuntas sedangkan gejala pelanggaran kian bertambah. Penyelesaian kasus Tanjung Priok, DOM Aceh, Papua dan kasus pelanggaran HAM berat di Timor-timur selama pra dan pasca jajak pendapat belum ada yang terselesaikan. Atas kondisi ini sorotan dunia internasional terhadap Indonesia sehubungan dengan maraknya pelanggaran HAM yang terjadi kian menguat terlebih sorotan atas pertanggung jawaban pelanggaran HAM yang terjadi di Timor-timur selama proses jajak pendapat.

Kasus pembumihangusan di Timor-timur telah mendorong dunia internasional agar dibentuk peradilan internasional (internasional tribunal) bagi para pelakunya. Desakan untuk adanya peradilan internasional khususnya bagi pelanggaran HAM yang berat yang terjadi di Timor- timur semakin menguat bahkan komisi Tinggi PBB untuk Hak-hak asasi manusia telah mengeluarkan resolusi untuk mengungkapkan kemungkinan terjadinya pelanggaran HAM berat di Timor-Timur. Atas resolusi Komisi HAM PBB tersebut Indonesia secara tegas menolak dan akan menyelesaikan kasus pelanggaran HAM dengan menggunakan ketentuan nasional karena konstitusi Indonesia memungkinkan untuk menyelenggarakan peradilan hak asasi manusia. Atas penolakan tersebut, mempunyai konsekuensi bahwa Indonesia harus melakukan proses peradilan atas terjadinya pelanggaran HAM di TimorTimur. Dorongan untuk adanya pembentukan peradilan internasional ini juga didasarkan atas ketidak percayaan dunia internasional pada sistem peradilan Indonesia jika dilihat antara keterkaitan antara pelaku kejahatan yang merupakan alat negara. Pelanggaran HAM di Timor-timur mempunyai nuansa khusus karena adanya penyalahgunaan kekuasaan dalam arti pelaku berbuat dalam konteks pemerintahan dan di fasilitasi oleh kekuasaan pemerintah sehingga akan sulit untuk diadakan pengadilan bagi pelaku kejahatan secara fair dan tidak memihak.

Dalam prakteknya jika melihat bekerjanya sistem peradilan pidana dinegara hukum Indonesia ini, belum mampu memberikan keadilan yang subtansial. Keterkaitan dengan kebijakan yang formal/legalistic seringkali dijadikan alasan. Peradilan sering kali memberikan toleransi terhadap kejahatan-kejahatan tertentu, dengan konsekuensi yuridis pelaku kejahatannya harus dibebaskan. Termasuk terhadap kejahatan atau pelanggaran HAM berat ini (Krist 2000).

Ketentuan dalam Kitab Undang-undang Hukum Pidana Indonesia yang berkaitan dengan pelanggaran HAM yang berat juga mengatur tentang jenis kejahatan yang berupa pembunuhan, perampasan kemerdekaan, penyiksaan/penganiayaan, dan perkosaan. Jenis kejahatan yang diatur dalam KUHP tersebut adalah jenis kejahatan yang sifatnya biasa (ordinary crimes) yang jika dibandingkan dengan pelanggaran HAM yang berat harus memenuhi 
beberapa unsur atau karakteristik tertentu yang sesua idengan Statuta Roma 1999 untuk bisa diklasifikasikan sebagai pelanggaran HAM yang berat. Pelanggaran HAM beratitu sendiri merupakan extra-ordinary crimes yang mempunyai perumusan dan sebab timbulnya kejahatan yang berbeda dengan para pelaku pelanggaran HAM yang berat. Disamping itu sesuai dengan prinsip International Criminal Court, khususnya prinsip universal yang tidak mungkin memperlakukan pelanggaran HAM berat sebagai ordinary crimes dan adanya kualifikasi universal tentang crimes against humanity masyarakat mengharuskan didayagunakannya pengadilan HAM yang bersifat khusus, yang mengandung pula acara pidana yang bersifat khusus (Muladi 2000).

Pengertian tentang perlunya peradilan yang secara khusus dengan aturan yang bersifat khusus pula inilah yang menjadi landasan pemikiran untuk adanya pengadilan khusus yang dikenal dengan pengadilan HAM. Alasan yuridis lainnya yang bisa menjadi landasan berdirinya pengadilan nasional adalah bahwa pengadilan nasional merupakan "the primary forum" untuk mengadili para pelanggar HAM berat (Muladi 2000)

\section{Eksistensi Pengadilan Hak Asasi Manusia Terhadap Suatu Perkara}

Konsideran dari Undang-Undang Nomor 26 Tahun 2000 ini menyatakan bahwa untuk ikut serta memelihara perdamaian dunia dan menjamin pelaksanaan hak asasi manusia serta memberi perlindungan, kepastian, keadilan, dan perasaan aman kepada perorangan ataupun masyarakat, perlu segera dibentuk suatu Pengadilan Hak Asasi Manusia untuk menyelesaikan pelanggaran hak asasi manusia yang berat sesuai dengan ketentuan Pasal 104 ayat (1) Undang-undang Nomor 39 Tahun 1999 tentang Hak Asasi Manusia.

Bahwa pembentukan Pengadilan Hak Asasi Manusia untuk menyelesaikan pelanggaran hak asasi manusia yang berat telah diupayakan oleh Pemerintah berdasarkan Peraturan Pemerintah Pengganti UndangUndang Nomor 1 Tahun 1999 tentang Pengadilan Hak Asasi Manusia yang dinilai tidak memadai, sehingga tidak disetujui oleh Dewan Perwakilan Rakyat Republik Indonesia menjadi Undang-Undang, dan oleh karena itu Peraturan Pemerintah Pengganti Undang-undang tersebut perlu dicabut. Berdasarkan pertimbangan diatas maka Pengadilan HAM perlu dibentuk.

Undang-undang No. 26 tahun 2000 tentang pengadilan ini memberikan 3 mekanisme untuk penyelesaian kasus-kasus pelanggaran HAM yang berat. Pertama adalah mekanisme pengadilan HAM ad hoc untuk pelanggaran HAM masa lalu sebelum adanya undang-undang ini, artinya untuk kasus-kasus yang terjadi sebelum tahun 2000 maka akan dibentuk pengadilan HAM ad hoc. Kedua adalah pengadilan HAM yang sifatnya permanen terhadap kasus setelah terbentuknya UU No. 26 Tahun 2000 dan yang Ketiga adalah dibukanya jalan mekanisme komisi kebenaran dan rekonsiliasi untuk penyelesaian pelanggaran HAM yang berat Pasal 47 Undang-Undang Nomor 26 Tahun 2000.

Pembentukan pengadilan HAM yang mengadili kejahatan terhadap kemanusiaan dan kejahatan genosida ini dianggap tidak tepat dan banyak dikritik sebagai pengaturan yang kurang tepat. Kesalahan ini yang terutama adalah memasukkan kejahatan terhadap kemanusiaan dan kejahatan genosida dalam istilah pengadilan HAM. Pelanggaran HAM yang berat dengan dua jenis kejahatan tersebut adalah kejahatan yang merupakan bagian dari hukum pidana karena merupakan bagian dari international crimes sehingga yang digunakan adalah seharusnya terminology "peradilan pidana."

Secara yuridis seharusnya pengklasifikasian kejahatan terhadap kemanusiaan dan kejahatan genosida diintegrasikan ke dalam kitab undangundang hukum pidana melalui amandemen. Dengan memasukkan jenis 
kejahatan ini kedalam Kitab Undang-Undang Hukum Pidana maka tidak akan melampaui asas legalitas. Sedangkan pelanggaran HAM yang dilakukan sebelum adanya amandemen tersebut seharusnya dibentuk mahkamah peradilan pidana ad hoc untuk kasus tertentu. Pandangan ini sejalan dengan pemahaman bahwa pelanggaran HAM yang berat termasuk kejahatan terhadap kemanusiaan dan kejahatan genosida secara yuridis seharusnya mengalami transformasi menjadi tindak pidana dan peradilan yang berwenang adalah peradilan pidana.

Dari argumen tentang "ketidaktepatan" ini menjadikan ada 2 lembaga yang mempunyai yurisdiksi untuk memeriksa dan mengadili perkara pidana yaitu peradilan pidana perkara pidana biasa dan pengadilan HAM untuk mengadili kejahatan yang tergolong pelanggaran HAM yang berat menurut Undang-Undang Nomor 26 Tahun 2000. Atas "ketidaktepatan" ini maka Undang-Undang Nomor 26 Tahun 2000 dianggap sebagai Undang-Undang yang sifatnya transisional sehingga untuk masa yang akan datang harus dirubah dan diintegrasikan ke dalam ketentuan pidana atau masuk peradilan pidana. Kritik atas keadaan ini adalah bahwa Undang-Undang Nomor 26 Tahun 2000 dianggap sebagai upaya praktis dari pemerintah untuk secara cepat mengakomodir dan menghentikan upaya-upaya ke arah peradilan internasional dan melupakan aspek-aspek yuridis.

Undang-Undang Nomor 26 Tahun 2000 tentang Pengadilan HAM ini juga dianggap mempunyai banyak kelemahan yang mendasar dalam pengaturannya.Undang-Undang Nomor 26 Tahun 2000 secara substansi banyak melakukan pengadopsian dari norma-norma hukum internasional terutama norma-norma dalam Rome Statute of International Criminal Court.

Kelemahan-kelemahan ini karena proses pengadopsian dari instrumen internasional yang tidak lengkap dan mengalami banyak kesalahan. Pengadopsian atas konsep kejahatan terhadap kemanusiaan dan tentang delik tanggung jawab komando tidak memadai sehingga banyak menimbulkan interpretasi dalam aplikasinya. Kelemahan lainnya adalah tidak ada hukum acara dan pembuktian secara khusus dan masih banyak menggunakan ketentuan yang berdasarkan Kitab Undang-undang Hukum Acara Pidana (KUHAP).

\section{c. Pengaturan tentang Pengadilan Hak Asasi Manusia Menurut Undang- Undang Nomor 26 Tahun 2000}

\section{Kedudukan dan Tempat Kedudukan}

Pengadilan HAM adalah pengadilan khusus yang berada di lingkungan peradilan umum. Kedudukannya di daerah kabupaten atau daerah kota yang daerah hukumnya meliputi daerah hukum Pengadilan Negeri yang bersangkutan, sedangkan daerah khusus ibukota pengadilan HAM berkedudukan di setiap wilayah Pengadilan Negeri yang bersangkutan. Pada saat undang-undang ini berlaku pertama kali maka pengadilan HAM dibentuk di Jakarta Pusat, Surabaya, Medan, dan Makassar.

Kedudukan dalam pengadilan HAM mengikuti Pengadilan Umum atau Pengadilan Negeri termasuk dukungan administrasinya. Hal ini membawa konsekuensi bahwa pengadilan HAM ini akan sangat tergantung dengan dukungan dari pengadilan negeri tersebut. Dukungan administratif itu adalah:

1. Ruangan pengadilan yang juga merupakan ruangan pengadilan untuk kasus lainnya dan tidak ada ruangan yang khusus untuk pengadilan HAM. Hal ini membawa konsekuensi bahwa jadwal persidangan akan sangat bergantung dengan jadwal persidangan kasus-kasus lainnya yang juga ditangani oleh Pengadilan Negeri tempat. 
2. Pengadilan HAM ini digelar. Dukungan staf administrasi : staf administrasi adalah staf yang menangani perkara pengadilan HAM selain panitera yang juga bertugas untuk membantu para hakim yang mengadili perkara pelanggaran HAM yang berat.

3. Dukungan panitera yang juga diambilkan dari Pengadilan Negeri setempat. Panitera ini adalah panitera biasa dan bukan panitera yang dibentuk khusus untuk menangani kasus pelanggaran HAM yang berat. Panitera ini juga menangani kasus lainnya.

4. Ruangan hakim : ruangan hakim untuk hakim ad hoc adalah ruangan tersendiri, namun untuk hakim karir yang merupakanhakim pengadilan setempat maka mereka mempunyai ruangan tersendiri.

\section{a. Kewenangan Memeriksa dan Mengadili}

Perkara pelanggaran HAM yang berat yang berwenang memutus dan memeriksa adalah pengadilan HAM.Kewenangan untuk memutus dan memeriksa juga termasuk menyelesaikan perkara yang menyangkut perkara tentang kompensasi, restitusi dan rehabilitasi bagi korban pelanggaran HAM berat sesuai dengan peraturan perundang-undangan yang berlaku. Kewenangan untuk memutus tentang kompensasi, restitusi dan rehabilitasi ini sesuai dengan Pasal 35 UU No. 26 Tahun 2000 yang menyatakan bahwa kompensasi, restitusi dan rehabilitasi dicantumkan dalam amar putusan pengadilan HAM.

Perkara pelanggaran HAM yang berat yang berwenang memutus dan memeriksa adalah pengadilan HAM. Kewenangan untuk memutus dan memeriksa juga termasuk menyelesaikan perkara yang menyangkut perkara tentang kompensasi, restitusi dan rehabilitasi bagi korban pelanggaran HAM berat sesuai dengan peraturan perundang-undangan yang berlaku. Kewenangan untuk memutus tentang kompensasi, restitusi dan rehabilitasi ini sesuai dengan Pasal 35 UU No. 26 Tahun 2000 yang menyatakan bahwa kompensasi, restitusi dan rehabilitasi dicantumkan dalam amar putusan pengadilan HAM.

UU No. 26 Tahun 2000 memberikan larangan atau membatasi kewenangan untuk memeriksa dan memutus perkara pelanggaran hak asasi manusia yang berat yang dilakukan oleh seseorang yang berumur di bawah 18 (delapan belas) tahun pada saat kejahatan dilakukan. Disini diartikan bahwa seseorang yang berumur dibawah 18 tahun yang melakukan pelanggaran HAM yang berat diperiksa dan diputus dalam Pengadilan Negeri. Ketentuan tentang pembatasan perkecualian yurisdiksi terhadap mereka yang berumur dibawah 18 tahun pada saat tindak pidana dilakukan (exclusion of jurisdiction over personunder eighteen) sesuai dengan norma yang diatur dalam Statuta Roma 1998.

\section{b. Jenis Kejahatan yang Dapat Diadili}

Jenis kejahatan yang dikategorikan sebagai pelanggaran HAM berat yang dapatdiperiksa atau diputus dan merupakan yurisdiksi pengadilan HAM adalah :

1. Kejahatan genosida yaitu setiap perbuatan yang dilakukan dengan maksud untuk menghancurkan atau memusnahkan seluruh atau sebagian kelompok bangsa, ras, kelompok etnis, kelompok agama, dengan cara :

a. Membunuh anggota kelompok;

b. Mengakibatkan penderitaan fisik atau mental yang berat terhadap anggota-anggota kelompok; 
c. Menciptakan kondisi kehidupan kelompok yang akan mengakibatkan kemusnahan secara fisik baik seluruh atau sebagian;

d. Memaksakan tindakan-tindakan yang bertujuan mencegah kelahiran di dalam kelompok atau;

e. Memindahkan secara paksa anak-anak dari kelompok tertentu ke kelompok lain.

2. Kejahatan terhadap kemanusiaan yaitu salah satu perbuatan yang dilakukan sebagai bagian dari serangan yang meluas atau sistematik yang diketahuinya bahwa serangan itu ditujukan secara langsung kepada penduduk sipil yang berupa:

a. Pembunuhan, dengan rumusan delik sebagaimana Pasal 340 KUHP.

b. Pemusnahan, yaitu meliputi perbuatan yang menimbulkan penderitaan yang dilakukan dengan sengaja, antara lain berupa perbuatan menghambat pemasokan barang makanan dan obatobatan yang dapat menimbulkan pemusnahan pada sebagian penduduk.

c. Perbudakan, dalam ketentuan ini termasuk perdagangan manusia, khususnya perdagangan wanita dan anak-anak.

d. Pengusiran dan pemindahan penduduk secara paksa, yaitu pemindahan orang-orang secara paksa dengan cara pengusiran atau tindakan pemaksaan yang lain dari daerah dimana mereka bertempat tinggal secara sah, tanpa disadari alasan yang diijinkan oleh hukum internasional.

e. Perampasan kemerdekaan atau perampasan kebebasan fisik lain secara sewenang-wenang yang melanggar (asas-asas) ketentuan pokok hukum internasional.

f. Penyiksaan, yaitu sengaja melawan hukum menimbulkan kesakitan atau penderitaan yang berat baik fisik maupun mental, terhadap seorang tahanan atau seorang yang berada di bawah pengawasan.

g. Perkosaan, perbudakan seksual, pelacuran secara paksa, pemaksaan kehamilan, pemandulan atau sterilisasi secara paksa atau bentukbentuk kekerasan seksual lain yang setara.

h. Penganiayaan terhadap suatu kelompok tertentu atau perkumpulan yang didasari persamaan paham politik, ras, kebangsaan, etnis, budaya, agama, jenis kelamin atau alasan lain yang telah diakui secara universal sebagai hal yang dilarang menurut hukum internasional.

i. Penghilangan orang secara paksa, yaitu penangkapan, penahanan, atau penculikan seseorang oleh atau dengan kuasa, dukungan atau persetujuan dari negara atau kebijakan organisasi, diikuti oleh penolakan untuk mengakui perampasan kemerdekaan tersebut, dengan maksud untuk melepaskan dari perlindungan hukum dalam jangka waktu yang panjang.

j. Kejahatan apartheid, yaitu perbuatan tidak manusiawi dengan sifat yang sama dengan sifat-sifat yang disebutkan dalam Pasal 8 yang dilakukan dalam konteks suatu rezim kelembagaan berupa penindasan dan dominasi oleh suatu kelompok rasial atas suatu kelompok atau kelompok-kelompok ras lain dan dilakukan dengan maksud untuk mempertahankan rezim itu.

Pengaturan tentang kejahatan genosida dan kejahatan terhadap kemanusiaan dalam UUNo. 26 Tahun 2000 dalam penjelasannya dinyatakan sebagai ketentuan yang sesuai dengan Rome Statute of 
International Criminal Court 1998. Penjelasan tersebut mempunyai konsekuensi bahwa kejahatan genosida dan kejahatan terhadap kemanusiaan seperti yang tercantum dalam Pasal 7 UU No. 26 Tahun 2000 sama maksudnya dengan Pasal 6 dan 7 dalam Statuta Roma 1998 termasuk terhadap penyesuaian unsur-unsur tindak pidananya (element of crimes). Definisi tentang kejahatan genosida dalam Pasal 8 UU No. 26 Tahun 2000 secara umum tidak ada persoalan dalam artian sudah sesuai dengan beberapa norma yang berkaitan dengan pengaturan genosida dalam ketentuan hukum internasional. Ketentuan tersebut adalah Pasal 6 dari Statuta Roma tentang ICC dan Article II Genocide Convention 1948 yang mendefinisikan genosida sebagai 5 (lima) perbuatan tertentu atau khusus yang dilakukan dengan maksud untuk memusnahkan (intent to destroy) suatu kelompok etnis, rasial atau agama.

Berbeda dengan pengertian tentang kejahatan genosida, definisi tentang kejahatan terhadap kemanusiaan dianggap banyak mengalami distorsi terutama dalam beberapa pengertian kunci tentang delik kejahatan ini. Dari proses adopsi tentang kejahatan terhadap kemanusiaan dan kejahatan genosida dari Statuta Roma kedalam UU No. 26 Tahun 2000 ini terdapat distorsi yang secara teoritis melemahkan konsep kejahatan tersebut terutama konsep tentang kejahatan terhadap kemanusiaan yaitu Tidak ada kejelasan mengenai unsur meluas (widespread), sistematik (systematic) dan diketahui (intension), hal ini akan berakibat adanya berbagai macam interpretasi atas pengertian di atas. Hal ini berbeda dengan ketentuan dalam Statuta Roma yang menjelaskan secara tegas mengenai intension (Elsam, 2003), Penerjemahan directed against any civillian population menjadi ditujukan secara langsung kepada penduduk sipil, yang seharusnya ditujukan kepada populasi sipil. Kata "langsung" ini bisa berimplikasi pada seolah-olah hanya pelaku di lapangan saja yang dapatdikenakan pasal ini sedangkan pelaku diatasnya yang membuat kebijakan tidak tercakup dalam pasal ini. Istilah "penduduk" untuk menterjemahkan kata "population" telah menyempitkan subyek hukum dengan menggunakan batasan-batasan wilayah yang akan menyempitkan target-target potensial korban kejahatan terhadap kemanusiaan hanya kepada warga negara dimana kejahatan tersebut berlangsung, Penerjemahan istilah "prosecution" menjadi penganiayaan. Prosecution mempunyai arti yang lebih luas merujuk pada perlakuan diskriminatif yang menghasilkan kerugian mental maupun fisik atau ekonomis. Dengan digunakan istilah penganiayaan ini maka tindakan teror dan intimidasi atas seseorang atau kelompok sipil tertentu berdasarkan kepercayaan politik menjadi tidak termasuk dalam kategori tersebut, UU No. 26 Tahun 2000 tidak memasukkan tentang kejahatan yang termasuk rumusan kejahatan terhadap kemanusiaan seperti dalam huruf $\mathrm{k}$ Pasal 7 Statuta Roma yaitu perbuatan tidak manusiawi lain dengan sifat yang sama secara sengaja menyebabkan penderitaan berat, atau luka serius terhadap badan atau mental atau kesehatan fisik. Alasan tidak dimasukkan rumusan ketentuan ini dalam UU No. 26 Tahun 2000 adalah adanya pengertian bahwa ketentuan ini tidak memberikan kepastian hukum dan memiliki penafsiran yang luas.

\section{Pengadilan HAM Ad Hoc}

Pengadilan HAM ad hoc adalah pengadilan yang dibentuk khusus untuk memeriksa dan memutus perkara pelanggaran HAM yang berat yang dilakukan sebelum adanya UU No. 26 Tahun 2000. Hal inilah yang membedakan dengan pengadilan HAM permanen yang dapat memutus dan 
mengadili perkara pelanggaran HAM yang berat yang terjadi setelah diundangkannya UU No. 26 Tahun 2000.

Kasus pelanggaran HAM yang berat yang terjadi di Indonesia misalnya untuk kasus pelanggaran HAM di Tanjung Priok dan Timur-timur dapat diselesaikan melalui pengadilan HAM ad hoc ini. Sampai saat ini sudah berdiri pengadilan HAM ad hoc untuk kasus pelanggaran HAM yang berat yang terjadi di Timor-timur dan Tanjung Priok.

Pengalaman pengadilan HAM ad hoc menunjukkan bahwa penerapan ketentuan dalam Undang-Undang Nomor 26 Tahun 2000 tidak dapat diaplikasikan secara konsekuen karena pengaturan yang lemah. Disamping itu terobosan hukum juga banyak dilakukan oleh majelis hakim yang menangani perkara pelanggaran HAM di Timor-timur ini.

\section{a. Legitimasi Berdirinya Pengadilan HAM Ad Hoc}

Legitimasi atas adanya pengadilan HAM ad hoc didasarkan pada Pasal 43 UU No. 26 tahun 2000. Ayat (1) menyatakan bahwa pelanggaran HAM berat yang terjadi sebelum diundangkannya undang-undang ini, diperiksa dan diputus oleh pengadilan HAM ad hoc. Ayat (2) menyatakan bahwa pengadilan HAM ad hoc sebagaimana dimaksud dalam ayat 1 dibentuk atas usul Dewan Perwakilan Rakyat berdasarkan peristiwa tertentu dengan keputusan presiden. Ayat (3) menyatakan bahwa pengadilan sebagaimana dimaksud dalam ayat (1) berada dalam pengadilan umum. Dalam penjelasannya, Dewan Perwakilan Rakyat yang juga sebagai pihak yang mengusulkan dibentuknya pengadilan HAM ad hoc mendasarkan usulannya pada dugaan terjadinya pelanggaran HAM yang berat yang dibatasi pada locus delicti dan tempos delicti tertentu yang terjadi sebelum diundangkannya undang-undang ini.

Ketentuan tentang adanya bebarapa tahap untuk diadakannya pengadilan HAM ad hoc terhadap kasus pelanggaran HAM yang berat yang berbeda dengan pengadilan HAM biasa. Hal-hal yang merupakan syarat adanya pengadilan HAM ad hoc yaitu :

1. Dugaan adanya pelanggaran HAM ad hoc yang terjadi sebelum Tahun 2000 atau sebelum disyahkannya UU No. 26 Tahun 2000.

2. Adanya dugaan pelanggaran HAM yang berat atas hasil penyelidikan Komnas HAM.

3. Adanya hasil penyidikan dari Kejaksaan Agung.

4. Adanya rekomendasi DPR kepada pemerintah untuk mengusulkan pengadilan HAM ad hoc dengan tempos dan locus delicti tertentu.

5. Adanya keputusan presiden (Keppres) untuk berdirinya pengadilan HAM ad hoc.

Ketentuan Pasal 43 UU No. 26 Tahun 2000 tidak mengatur secara jelas mengenai alur atau mekanisme bagaimana sebetulnya proses perjalanan pembentukan pengadilan HAM ad hoc setelah adanya penyelidikan dari Komnas HAM tentang adanya pelanggaran HAM yang berat. Pengalaman pengadilan HAM ad hoc untuk kasus pelanggaran HAM berat di Timor-timor menjelaskan bahwa mekanismenya adalah Komnas HAM melakukan penyelidikan lalu hasilnya diserahkan ke kejaksaan agung, Kejaksaan agung melakukan penyidikan. Hasil penyidikan diserahkan ke Presiden. Presiden mengirimkan surat ke DPR lalu DPR mengeluarkan rekomendasi. Kemudian Presiden mengeluarkan keppres yang melandasi dibentuknya pengadilan HAM ad hoc. 


\section{d. Pengadilan Hak Asasi Manusia dalam Mewujudkan Tujuan Hukum ada Sistem Peradilan Pidana}

\section{Hukum Acara Pengadilan Hak Asasi Manusia}

Pasal 10 UU No. 26 Tahun 2000 menyatakan bahwa hukum acara yang digunakan adalah hukum acara yang berdasarkan hukum acara pidana kecuali ditentukan lain dalam undang-undang ini. Hal ini berarti hukum acara yang akan digunakan untuk proses pemeriksaan dipengadilan menggunakan hukum acara dengan mekanisme sesuai dengan Kitab Undang-undang Hukum Acara Pidana (KUHAP).

UU No. 26 Tahun 2000 mengatur Kekhususan pengadilan HAM di luar ketentuan KUHAP untuk pelanggaran HAM yang berat. Kekhususan dalam penanganan pelanggaran HAM yang berat dalam UU No. 26 Tahun 2000 adalah :

1. Diperlukan penyelidik dengan membentuk tim ad hoc, penyidik ad hoc, penuntut ad hoc, dan hakim ad hoc.

2. Diperlukan penegasan bahwa penyelidik hanya dilakukan oleh komisi nasional hak asasi manusia sedangkan penyidik tidak berwenang menerima laporan atau pengaduan sebagaimana diatur dalam KUHAP.

3. Diperlukan ketentuan mengenai tenggang waktu tertentu untuk melakukan penyidikan, penuntutan, dan pemeriksaan di pengadilan.

4. Diperlukan ketentuan mengenai perlindungan korban dan saksi.

5. Diperlukan ketentuan mengenai tidak ada kadaluarsa pelanggaran HAM yang berat.

Kekhususan ini kemudian dijabarkan dalam pasal demi pasal dalam UU No. 26 Tahun 2000 yang merupakan pengecualian dari pengaturan dalam KUHAP yaitu :
a. Penyelidikan
b. Penyidikan
c. Penangkapan
d. Penahanan
e. Penuntutan
f. Pemeriksaan di sidang pengadilan
g. Perlindungan saksi dan korban
h. Kompensasi, restitusi dan rehabilitasi
i. Ketentuan mengenai tidak berlakunya asas daluwarsa

\section{Hukum Acara Pengadilan HAM Ad Hoc}

Pasal 44 UU No. 26 Tahun 2000 menyatakan bahwa pemeriksaan di pengadilan HAM ad hoc dan upaya hukumnya dilakukan sesuai dengan ketentuan dalam undang-undang ini. Hal ini berarti bahwa hukum acara yang digunakan dalam pengadilan HAM ad hoc sama dengan ketentuan yang digunakan dalam pengadilan HAM yaitu menggunakan ketentuan dalam UU No. 26 Tahun 2000. Seperti halnya dengan Pengadilan HAM, ketentuan mengenai hukum acara yang digunakan juga mengacu pada Pasal 10 UU No. 26 Tahun 2000 yang mensyaratkan digunakannya ketentuan dalam KUHAP kecuali yang ditentukan secara khusus dalam UU No. 26 Tahun 2000.

Hukum acara yang digunakan dalam pengadilan HAM ad hoc dalam prakteknya ternyata juga mengalami beberapa hambatan. Pengalaman pengadilan HAM ad hoc untuk kasus pelanggaran HAM berat di Timortimur bisa menjadi referensi yang dapat digunakan untuk menganalisa efektivitas berlakunya. Beberapa contoh penerapan hukum acara dalam 
proses peradilan HAM ad hoc kasus pelanggaran HAM berat di Timortimur mengenai hal-hal sebagai berikut :

\section{a. Jangka Waktu Penyidikan dan Penuntutan Pemeriksaan di Sidang Pengadilan}

Adanya limitasi jangka waktu untuk proses penyelidikan dan penuntutan menjadi batasan bagi pihak penyidik dan penuntut umum untuk melakukan proses penyidikan dan penuntutan. Dalam berbagai kasus yang disidangkan untuk pelanggaran HAM yang berat di Timortimur ini nota keberatan/eksepsi dari terdakwa terhadap proses pemeriksaan dan penuntutan yang dianggap tidak sesuai atau sudah melampaui ketentuan undang-undang. Ketentuan tentang jangka waktu ini terdapat ketidakjelasan mengenai jangka waktu antara penyidikan dinyatakan selesai dan kapan hasil penyidikan itu harus diserahkan untuk dilakukan penuntutan. Dalam UU No. 26 Tahun 2000 hanya dinyatakan bahwa penuntutan harus diselesaikan dalam jangka waktu 70 hari terhitung sejak tanggal hasil penyelidikan diterima. Jadi UU No. 26 Tahun 2000 hanya mengatur tentang lama penyidikan dan lama penuntutan tetapi tidak diatur mengenai kewajiban atau batasan waktu diserahkannya hasil penyelidikan ke penuntutan.

\section{b. Jangka Waktu Pemeriksaan di Sidang Pengadilan}

Ketentuan Pasal 31 yang menyatakan pengadilan mempunyai jangka waktu selama 180 hari untuk memeriksa dan memutus perkara pelanggaran HAM yang berat ternyata juga tidak dapat diterapkan sepenunya dalam proses peradilan HAM ad hoc ini. Beberapa majelis hakim membuat ketetapan-ketetapan untuk adanya perpanjangan masa persidangan ketika melewati masa 180 hari. Alasan perpanjangan ini adalah dikarenakan kurangnya waktu yang diperlukan oleh majelis hakim untuk mencari kebenaran materiil.

\section{c. Proses Pembuktian}

Selama proses pemeriksaan kesaksian terutama terhadap saksi korban mekanismenya menggunakan pemeriksaan biasa dalam artian saksi menghadiri persidangan untuk memberikan keterangannya sesuai dengan ketentuan KUHAP. Mekanisme tentang dapat digunkannya pemeriksaan kesaksian tanpa hadirnya terdakwa juga tidak pernah dipakai selama proses pemeriksaan kesaksian, demikian juga dengan hak saksi dan korban untuk dirahasiakan identitasnya. Proses pemeriksaan saksi yang termasuk progresif adalah diijinkannya videoconference untuk pemeriksaan saksi. Proses pemeriksaan melalui videoconference ini adalah sebetulnya belum diatur dalam hukum acara kita (KUHAP) tetapi majelis hakim yang mengijinkan adanya video conference ini mengacu pada praktek peradilan internasional.

Prosedur pembuktian dan alat bukti yang digunakan selama proses peradilan tidak cukup memadai. Dilihat dari alat bukti yang ditampilkan di muka persidangan tidak bisa dilihat atau menunjukkan secara pasti dan detail tentang terjadinya perkara. Demikian pula dengan para saksi terutama saksi korban yang sulit menggambarkan secara detail, jelas dan konkret tentang unit militer ,polisi atau sipil bersenjata, seragam dan siapa yang melakukan langsung. Hal ini pada gilirannya akan sangat sulit untuk mendapatkan bukti tentang adanya "command responsibility". 


\section{KESIMPULAN}

Berdasarkan pembahasan diatas, maka dapat disimpulkan bahwa eksistensi Pengadilan HAM terhadap suatu perkara berdasarkan UU No.26 Tahun 2000 tentang Pengadilan HAM adalah yurisdiksi untuk memeriksa dan memutus perkara pelanggaran HAM yang berat yaitu kejahatan terhadap kemanusiaan dan kejahatan genosida. UU No. 26 Tahun 2000 tentang pengadilan HAM masih banyak mengandung kelemahan-kelemahan yang mengakibatkan hambatan-hambatan yuridis dalam penerapan UU No. 26 Tahun 2000 tersebut. Kelemahan-kelemahan tersebut antara lain tidak secara lengkap menyesuaikan tindak pidana yang diatur yaitu kejahatan terhadap kemanusiaan dan kejahatan genosida yang seharusnya juga disertai dengan penjelasan mengenai unsur-unsur tindak pidananya (elements of crimes). UU No. 26 Tahun 2000 tentang Pengadilan HAM ini juga tidak mengatur tentang prosedur pembuktian secara khusus untuk mengadili kejahatan yang sifatnya "extraordinary crimes". Bahwa dalam pengadilan HAM dalam sistem peradilan pidana dapat mewujudkan kepastian hukum jika dilihat dari Pasal 44 UU No. 26 Tahun 2000 menyatakan bahwa pemeriksaan di pengadilan HAM ad hoc dan upaya hukumnya dilakukan sesuai dengan ketentuan dalam undangundang ini. Hal ini berarti bahwa hukum acara yang digunakan dalam pengadilan HAM ad hoc sama dengan ketentuan yang digunakan dalam pengadilan HAM yaitu menggunakan ketentuan dalam UU No. 26 Tahun 2000. Seperti halnya dengan Pengadilan HAM, ketentuan mengenai hukum acara yang digunakan juga mengacu pada Pasal 10 UU No. 26 Tahun 2000 yang mensyaratkan digunakannya ketentuan dalam KUHAP kecuali yang ditentukan secara khusus dalam UU No. 26 Tahun 2000.

\section{SARAN}

Adapun saran yang dapat diberikan bahwa Agar eksistensi pengadilan HAM terhadap suatu perkara dapat terselesaikan dengan baik dalam penerapan Undang-Undang No. 26 Tahun 2000 tentang pengadilan HAM pemerintah perlu mengamandemen UU No.26 Tahun 2000 agar secara lengkap menyesuaiakan tindak pidana yang diatur yaitu kejahatan terhadap kemanusiaan dan kejahatan terhadap genosida yang seharusnya disertai dengan penjelasan mengenai unsur tindak pidananya. Seharusnya agar pengadilan HAM dalam sistem peradilan pidana mewujudkan kepastian hukum tercapai maka sebaiknya Presiden sebagai kepala Negara segera menindaklanjuti rekomendasi DPR terhadap semua kasus pelanggaran HAM terkhususnya kasus pelanggaran HAM yang berat dengan sesegera mungkin mengeluarkan Keppres pembentukan Pengadilan HAM Ad Hoc untuk semua kasus pelanggaran HAM yang pernah terjadi.

\section{DAFTAR PUSTAKA}

\section{a. Buku}

Abdul Muin Salim, 2002, Islam dan Global Peace, Yogyakarta, Madyan Press. Elsam, 2003, Progres Report Pemantauan Pengadilan Hak Asasi Manusia.

Franz Magnis Suseno, 2001, Etika Politik, Prinsip-Prinsip Moral Dasar Kenegaraan Modern, Jakarta.

Muladi, 2004, Mekanisme Domestik untuk Mengadili Pelanggaran HAM Berat melalui Sistem Pengadilan atas Dasar UU No.26 Tahun 2000,Makalah dalam Diskusi Panel 4 bulan Pengadilan Tanjung Priok, Jakarta , 2000, Pengadilan Pidana bagi Pelanggar HAM Berat di Era Demokrasi,Jakarta. 
E-ISSN: 2614-5030, P-ISSN: 2614-5022 Volume 2 No. 1 - April 2019

Madernis, 2016, Pendidikan Kewarganegaraan dalam Rangka Pengembangan Kepribadian Bangsa, Rajawali Pers, Jakarta.

Miriam Budiarjo, 2000, Dasar-Dasar Ilmu Politik, Gramedia Pustaka Utama, Jakarta.

Krist L. Kleden, 2000, Peradilan Pidana sebagai Pendidikan Hukum, Jakarta.

Todung Mulya Lubis, 2002, Jaminan Konstitusi atas HAM dan Kebebasan, Jakarta.

\section{b. Undang Undang}

Undang-Undang Dasar Negara Republik Indonesia Tahun 1945

Undang-Undang No. 39 Tahun 1999 Tentang Hak Asasi Manusia.

Undang-Undang NO. 26 Tahun 2000 Tentang Pengadilan Hak Asasi Manusia 